DOI 10.15290/cnisk.2016.01.01.10

DR HAB. MAtGORZATA DAJNOWICZ, PROF. UWB

Uniwersytet w Białymstoku

\title{
Natalia Jarska, Kobiety z Marmuru. Robotnice w Polsce w latach 1945-1960, Instytut Pamięci Narodowej, Warszawa 2015, ss. 368, ISBN 978-83-7629-764-4
}

Monografia naukowa Natalii Jarskiej, której podstawą była praca doktorska obroniona przez Autorkę w Instytucie Historii Polskiej Akademii Nauk w 2014 r., jest poważnym osiagnięciem badawczym, wnoszącym wiele nieznanych faktów do historii kobiet okresu Polskiej Rzeczpospolitej Ludowej. Dotychczas główne akcenty w badaniach dziejów kobiet $\mathrm{z}$ ziem polskich kładziono na zagadnienia dotyczace okresu XIX i pierwszej połowy XX wieku (do 1939 r.), co znalazło odzwierciedlenie w programie badawczym zainicjowanym przez Annę Żarnowską i Andrzeja Szwarca1, kontynuacją którego pozostają corocznie publikowane tomy².

1 Między innymi: Kobieta $i$ społeczeństwo na ziemiach polskich $w$ XIX wieku: zbiór studiów, red. A. Żarnowska, A. Szwarc, Warszawa 1990; Kobieta i świat polityki: Polska na tle porównawczym $w$ XIX i w początkach XX wieku: zbiór studiów, t. 3, red. A. Żarnowska, A. Szwarc, Warszawa 1994; Kobieta i świat polityki w niepodległej Polsce 1918-1939: zbiór studiów, t. 3, cz. 2, red. A. Żarnowska i A. Szwarc, Warszawa 1996; Kobieta i kultura życia codziennego: wiek XIX i XX: zbiór studiów, t. 5, red. A. Żarnowska i A. Szwarc, Warszawa 1997.

2 Przykładowo zwłaszcza: Kobiety i media. Studia $z$ dziejów emancypacji kobiet, red. P. Perkowski, T. Stegner, Gdańsk 2009; Kobieta $w$ gospodarstwie domowym. Ziemie polskie na tle porównawczym, red. K. Sierakowska, G. Wyder, Zielona Góra 2012 oraz inne opracowania zbiorowe, m.in.: Działaczki społeczne, feministki, obywatelki. Samoorganizowanie sie kobiet na ziemiach polskich po 1918 roku (na tle porównawczym), t. 1, red. A. Janiak-Jasińska, K. Sierakowska, A. Szwarc, Warszawa 2008; Działaczki społeczne, feministki, obywatelki: Samoorganizowanie sie kobiet na ziemiach polskich po 1918 roku (na tle porów- 
W zakresie badań historii kobiet po $1945 \mathrm{r}$. wciąż pozostaje wiele białych plam $^{3}$. Praca Natalii Jarskiej, obok książki Małgorzaty Fidelis ${ }^{4}$, stanowi w znaczacym zakresie punkt wyjściowy do kompleksowych opracowań dotyczących dziejów kobiet polskich okresu drugiej połowy XX wieku. W pewnym zakresie sama Autorka recenzowanej pracy wskazuje jednoznacznie na ubogi dorobek poświęcony współczesnej historii kobiet. Za nieprawdziwe natomiast należy uznać stwierdzenia, że Polska historiografia kończy się na 1945 roku, czy że nowościa sa konferencje $w$ całości poświęcone powojennej historii kobiet (s. 13). Można w tym miejscu wskazać chociażby na projekty Piotra Perkowskiego czy Katarzyny Stańczak-Wiślicz, badaczy zajmujących się miejscem kobiet $\mathrm{w}$ życiu społecznym Polski Ludowej. Warto wymienić również konferencję naukowa Komisji Historii Kobiet Polskiej Akademii Nauk pt. Drogi Kobiet do polityki (od XVIII do XXI wieku) ${ }^{5}$, współorganizowana przez Wydział Historyczno-Socjologiczny UwB i Instytut Studiów Kobiecych, podczas której wygłoszono referaty poświęcone także dziejom kobiet polskich, uczestniczących $\mathrm{w}$ polityce w drugiej połowie XX wieku6 .

nawczym), t. 2, red. A. Janiak-Jasinska, K. Sierakowska, A. Szwarc, Warszawa 2009; Aktywność publiczna kobiet na ziemiach polskich. Wybrane zagadnienia, red. T. Pudłocki, K. Sierakowska, Warszawa 2013 oraz pokłosie najnowszych badań: Postawy $i$ aktywność kobiet $w$ czasie powstania styczniowego 18631864 (na tle polskich konspiracji i działalności powstanczej doby zaborowej), red. T. Kulak, J. Dufrat, M. Piotrowska-Marchewa, Wrocław 2013; Kobiety $w$ wojnach $i$ konfliktach polityczno-społecznych na ziemiach polskich $w$ pierwszej połowie XX wieku, red. T. Kulak i A. Chlebowska, Wrocław 2014; Drogi kobiet do polityki (na przestrzeni XVIII-XXI wieku), red. T. Kulak i M. Dajnowicz, Wrocław 2016.

3 Zob. K. Stańczak-Wiślicz, P. Perkowski, Dzieje kobiet $w$ PRL - stan i perspektywy badawcze [w:] Dzieje kobiet w Polsce. Dyskusja wokół przyszłej syntezy, pod red. K. A. Makowskiego, Poznań 2014, s. 133-157.

4 M. Fidelis, Women, Communism, and Industrialization in Postwar Poland, New York 2010. Por. polski przekład: Eadem, Kobiety, komunizm i industrializacja $w$ powojennej Polsce, przeł. Maria Jaszczurowska, Warszawa: Wydawnictwo W. A. B., 2015.

5 Materiały $\mathrm{z}$ konferencji zostały opublikowane $\mathrm{w}$ przywoływanej monografii zbiorowej pod red. T. Kulak i M. Dajnowicz.

6 A. Chłosta-Sikorska, Polityczne uczestnictwo kobiet $w$ zjazdach Polskiej Zjednoczonej Partii Robotniczej z lat 1980-1986. Zarys problematyki [w:] Drogi kobiet do polityki... op. cit., s. 389-415. Do spuścizny PRL nawiąuje również opracowanie autorki recenzji: M. Dajnowicz, Wzorce aktywności publicznej kobiet $w$ poczat- 
W recenzowanej monografii Natalia Jarska przedstawiła zjawisko aktywności zawodowej polskich robotnic w latach 19451960. Badaniom poddała temat, analizujac go $z$ wykorzystaniem, jak podała, dwóch tradycji badawczych. Jedna $z$ tradycji wiąże się według Autorki $z$ refleksja nad przemianami roli społecznej kobiet w analizowanym okresie chronologicznym, druga zaś miałaby być analiza problematyki $z$ uwzględnieniem perspektywy płci kulturowej7. Autorka w przekonaniu o nadrzędnym znaczeniu badań zwiąanych $z$ płcia stwierdziła, że na dłuższa metę bez kategorii "gender" nie sposób uprawiać historii kobiet (s. 14). Należy w tym miejscu wnieść uwage krytyczna do tego stwierdzenia, które wydaje się nie mieć uzasadnienia w faktach, bowiem w moim przekonaniu od wielu lat, $z$ dobrymi wynikami prac (co sama Autorka wcześniej stwierdziła) prowadzi się badania historii kobiet bez prowadzenia interdyscyplinarnych studiów i warsztatu badawczego $z$ obszaru gender studies. Wprawdzie w monografii w wielu miejscach podkreśla się znaczenie płci kulturowej, jednak, w moim przekonaniu, N. Jarska nie wykazuje się konsekwencja i poza wspomnianym podkreślaniem znaczenia perspektywy badawczej płci kulturowej właściwie nie analizuje tematu $z$ wykorzystaniem metodologii genderowej. Według mnie temat został opracowany w oparciu o tzw. tradycyjne metody, od wielu lat wykorzystywane przez historyków badajacych dzieje kobiet.

W rozdziale pierwszym N. Jarska przedstawiła losy kobiet w trudnym okresie pierwszych lat powojennych. W oparciu o solidna baze materiałowa przedstawiono zagadnienie wpływu skutków II wojny światowej na położenie kobiet, przede wszystkim wdów i przymusowa w związku $z$ tym ich aktywizację zawodowa. $\mathrm{Na}$ konieczność podejmowania pracy przez kobiety, w tym rów-

kach transformacji ustrojowej $w$ Polsce $w$ świetle "Kobiety i Życia” i „Urody” (1989-1995) [w:] Drogi kobiet do polityki... op. cit., s. 417-443.

7 Według definicji zamieszczonej w encyklopedii PWN płeć kulturowa, płeć społeczna, ang. Gender, jest to identyfikacja jednostki $z$ rola płci wynikajaca z uwarunkowan kulturowych $i$ społecznych; płeć kulturowa ma charakter wyuczony; powstaje we wczesnym okresie socjalizacji (3-6 rok życia), $w$ czasie którego następuje uwewnętrznienie norm zwiazanych $z$ rolami płciowymi, [Dostęp: 11.08.2016]. Dostępny w World Wide Web: <http://encyklopedia.pwn.pl/ haslo/plec-kulturowa;3958385.html>. 
nież wcześniej niepracujące, bez kwalifikacji, wykształcenia i perspektyw na stabilna egzystencję miał wpływ przede wszystkim brak środków na utrzymanie ich samych i rodzin. W związku $z$ tym pracę podejmowały wdowy i kobiety $z$ rodzin o niskich dochodach, czyli niewystarczających na utrzymanie w budżecie domowym. Zwrócenie uwagi na ten problem i dalej temat powojennego bezrobocia kobiet, należy uznać za bardzo interesujaca i ważna cześć monografii. Autorka podaje przy tym, że w trudnej rzeczywistości powojennej, oprócz bezrobocia, kobiety doświadczały innych trudów w codziennej egzystencji, w tym także ulegały demoralizacji. Od 1947 r. rozpoczyna się w Polsce Ludowej tzw. akcja A-Z, w której udział biora kobiety, związana $z$ zatrudnianiem kobiet i masowym ich szkoleniem w celu dostosowania do rynku pracy. W upowszechnianie i organizowanie akcji szkoleń prowadzacych do zatrudniania kobiet włączyła się SpołecznoObywatelska Liga Kobiet. Autorka bardzo skrupulatnie analizuje programy państwa dotyczące likwidacji bezrobocia. Można w tym miejscu postawić pytanie, na które nie ma odpowiedzi w książce, o zakres i zasięg akcji propagandowych, nagłaśniajacych tematykę walki $z$ bezrobociem kobiet.

Autorka przedstawiła wartościowe analizy i ich opisy zatrudnienia kobiet, odnosząc się również do różnic w skali zatrudnienia i profilu wykonywanej pracy przed 1945 r. i po nim. Za naturalne zjawisko należy uznać zmniejszenie odsetka zatrudnienia w służbie domowej na rzecz pracy w przemyśle, porównujac okresy lat trzydziestych II Rzeczypospolitej i pierwszych lat PRL do 1950 r. Kobieta polska pierwszych lat Polski Ludowej, na wzór upowszechnianej w popularnym wówczas piśmie „Moda i Życie Praktyczne", do treści którego odnosiła się Autorka w wielu fragmentach książki, miała być kobieta pracująca i jednocześnie prowadzaca dom oraz w związku $z$ tym obciążona licznymi obowiązkami rodzinnymi. Oczywiste było, że zgodnie $z$ dominujacymi ówcześnie w społeczeństwie polskim wzorcami podziału ról na kobiece i męskie, kobiety w pełni akceptowały owe obciażenia domowe. Za wręcz infantylne należy uznać zdanie zawarte w książce że kobiety nie buntowały się [wówczas - M.D.] przeciw 
obciażeniu obowiazkami domowymi (s. 89). Należy podkreślić, że i wiele lat później ów bunt nie nastapił. Propagowanie wzorca angażowania $\mathrm{w}$ prace domowe mężczyzn zaczęto upowszechniać w społeczeństwie polskim, jednak wyłącznie miejskim, także na lamach najbardziej popularnego czasopisma kobiecego „Kobieta i Życie" dopiero od lat siedemdziesiątych. W grupie opisywanych robotnic, emigrantek ze wsi do miasta, w ich codziennych obyczajach i wyobrażeniach życia prywatnego ciażyła tradycja, zgodnie z którą za dom i rodzinę odpowiedzialna miała być kobieta, także pracująca $\mathrm{w}$ fabryce, a nawet $\mathrm{w}$ kopalni. Kobieta ta przenosiła $\mathrm{w}$ pewnym zakresie również wiejskie zwyczaje życia codziennego na grunt miejski, eksponowała przywiazanie do tradycji i religii, co było widoczne zwłaszcza w okresie przed 1950 r. Robotnice stanowiły wówczas około $36 \%$ kobiet zatrudnionych w sektorze pozarolniczym i rekrutowały się głównie ze wsi.

Za cenne fragmenty monografii należy uznać części dotyczace pracy kobiet $\mathrm{w}$ okresie stalinizmu i propagowanym wówczas modelu sukcesu kobiet, pracujących w nowych, męskich zawodach, równości rozumianej jako równy dostęp do środków produkcji, czyli pracy, upowszechniania współzawodnictwa w pracy. Słusznie wywodzi Autorka, że istotne znaczenie, wręcz przełomowe w zakresie wyznaczenia okresu początków produktywizacji, odnosi się uchwała Biura Politycznego KC PZPR z 1950 r. W myśl tej uchwały polskie kobiety miały awansować $\mathrm{w}$ pracy i być zatrudniane w skali bardziej masowej niż wcześniej. Perspektywę realizacji tej decyzji zapewniać miała industrializacja i realizacja planu 6-letnego, zaś narzędziem realizacji programu produktywizacji miała być $-z$ czym należy się zgodzić - Liga Kobiet. To Liga miała organizować szkolenia zawodowe, niekiedy pełniła rolę filii urzędów zatrudnienia kobiet i jako organizacja satelicka PZPR miała zapewniać realizację programu politycznego, określonego m.in. $\mathrm{w}$ planie 6-letnim. Chyba zbyt jednoznacznie stwierdzono w konkluzjach dotyczacych oceny pracy kobiet w okresie stalinizmu, że podział na zawody męskie i żeńskie przestał w tym czasie istnieć (s. 135). Wydaje się że podział ten był zakorzeniony również w świadomości społecznej i co za tym idzie przenosił się na tzw. 
praktykę, również $\mathrm{w}$ okresie nasilonej propagandy promowania przez władze PRL uprawiania przez kobiety zawodów np. traktorzystki czy murarki. Kobiety rezygnowały także $z$ pracy $w$ tym czasie, nie $z$ powodów niskich zarobków, jak pisze Autorka monografii, a raczej $z$ podwodów rodzinnych i środowiskowych, w tym presji społecznej głównie wobec mężatek, dotyczącej ich podstawowych i najważniejszych ról, ograniczonych do przestrzeni domowej. Co więcej, o tych podstawowych rolach matki i żony przekonane były również same kobiety, także robotnice, zwłaszcza pochodzace ze środowiska wiejskiego. W prasie kobiecej pojawiały się m.in. informacje o uciążliwościach dnia codziennego polskich kobiet, w tym o ich przemęczeniu, problemach zdrowotnych, brakach w zaopatrzeniu, skutkujacych problemami w żywieniu rodzin, niedostatecznej opieki państwa nad rodzina i dzieckiem. Mimo tych problemów, których doświadczały codziennie kobiety, również pracujace $\mathrm{w}$ zakładach przemysłowych robotni$\mathrm{ce}, \mathrm{w}$ latach pięćdziesiątych $\mathrm{w}$ odbiorze społecznym dominował wzorzec pełnej odpowiedzialności kobiet za funkcjonowanie rodziny i prowadzenie gospodarstwa domowego. W połowie lat pięćdziesiatych opinie społeczeństwa na temat zatrudnienia kobiet ukazywał przywoływany w ksiażce film pt. Irena do domu w reżyserii Jana Fethke. Zgodnie $z$ obowiąującym wówczas modelem społecznym, który popierały także kobiety, to mąż odpowiedzialny był za utrzymanie rodziny, zawodowa praca kobiet miała zaś mieć charakter wspierajacy dla podstawowego, zapewnionego przez mężczyznę budżetu domowego.

Bardzo interesujące fragmenty pracy dotycza udziału kobiet $\mathrm{w}$ polityce, w tym członkostwa kobiet w PZPR. Autorka wnikliwie przeanalizowała dostępne dane statystyczne dotyczace udziału procentowego i zmian zachodzacych $\mathrm{w}$ tym zakresie pod wzgledem udziału, zwłaszcza robotnic, w strukturach partyjnych. Przywołane dane zostały wnikliwie udokumentowane. Nieznana dotychczas wiedzę wnosi część pracy dotycząca zaangażowania robotnic w działalność Ligi Kobiet.

Od 1955 r. kurs polityczny wobec pracy kobiet uległ zmianie, co skutkowało wzrostem bezrobocia wśród kobiet $z$ jednej strony 
oraz rezygnacja części wcześniej zatrudnionych $z$ pracy zawodowej. Wpływ na ten stan rzeczy miała również działalność Ligi Kobiet, w której przekonywano kobiety do powrotu do domu. Był to również początek, jak słusznie zauważyła Autorka, krytyki wytycznych, dotyczacych zatrudnienia kobiet w zawodach męskich, forsowanych $\mathrm{w}$ okresie stalinizmu oraz postępujacych zmian w kwestii pracy kobiet w poszczególnych zawodach. Coraz częściej, co było w pełni akceptowane społecznie, kobiety pracowały jako nauczycielki, lekarki, urzędniczki, sekretarki i ekspedientki. Zarówno w prasie kobiecej, jak i dyskursie publicznym od około 1955 r. uzasadniano, że praca na stanowiskach robotniczych nie jest dla kobiet odpowiednia.

Za przykład do opisu wybrano fabrykę łożysk tocznych w Kraśniku, nietypowy zakład przemysłowy, utworzony na wschodzie Polski. Charakterystyce poddano robotnice tam pracujace, pochodzace ze wsi. Była to grupa funkcjonujaca zawodowo zarówno w kraśnińskim zakładzie, jak i gospodarstwach wiejskich (chłopo-robotnice). Charakterystyka grupy robotnic z Kraśnika jest bardzo interesujacca, choć wyrażam wątpliwość co do doboru do opisu przykładu fabryki. Zakład ten nie jest przykładem modelowym zakładu pracy polskich robotnic w opisywanym okresie chronologicznym - czego spodziewać się mógł czytelnik, analizujac tytuł monografii. W tym miejscu można się domyślić, że Autorka inspirowała się koncepcja opracowania tematu, wysunięta wcześniej, we wspomnianej pracy przez Małgorzatę Fidelis. W różnych fragmentach opracowania widać wyraźnie, że w poszczególnych partiach recenzowanej pracy inspirowano się książka Fidelis, również pod względem przyjęcia struktury pracy oraz opisu podejmowanych wątków, co w mojej opinii nie jest mankamentem monografii. W ocenie ram chronologicznych publikacji dość sztuczna wydaje się granica 1960 r. Pod względem zmian w zakresie ról kobiet w społeczeństwie PRL, w tym znaczenia pracy zawodowej kobiet na tle ówczesnej rzeczywistości, logiczniejszy wydaje się być rok 1970. Bowiem od jego początków następowały zmiany w tym zakresie, zapowiadajace niejako rok 1975, obwołany przez Organizację Narodów Zjednoczonych Rokiem Kobiet, co 
oznaczać miało intensyfikację działań, także w Polsce, zmierzających do zrównania pozycji kobiet $z$ mężczyznami w różnych przestrzeniach życia, w tym w polityce i pracy zawodowej.

Niektóre stwierdzenia Autorki budzą wątpliwości, zwłaszcza dotyczace płci kulturowej. Dla przykładu, niezrozumiałe wydaje się zdanie: Oddziaływanie płci kulturowej było więc niejednoznaczne $-z$ jednej strony hamowało zatrudnienie kobiet, $z$ drugiej mogło pozytywnie wpłynać na ich akceptacje jako nowych pracownic (s. 132). Tego typu konstatacji w monografii jest więcej. W mojej opinii Autorka zbyt swobodnie operuje pojęciem pleć kulturowa, nie zawsze trafnie w odniesieniu do poruszanych kwestii. Zbyt mała wage, co rzutuje później na interpretacje autorskie, przywiązuje do ciążenia postrzegania ról społecznych kobiet i mężczyzn oraz związanych $z$ tym stereotypów $z$ okresu międzywojnia. Należy zauważyć pewnego rodzaju kontynuację stereotypowego postrzegania pracy zawodowej kobiet w kulturze chłopskiej, przeniesione $z$ okresu sprzed 1939 r. na środowiska robotnicze po 1945 r., robotnice zresztą o rodowodzie chłopskim.

Dobrze się jednak stało, że ukazała się recenzowana monografia autorstwa Natalii Jarskiej pt. Kobiety z Marmuru. Robotnice $w$ Polsce $w$ latach 1945-1960. Oceniam ja jako bardzo wartościową, wnoszaca wiele nieznanych faktów do historii ruchu robotniczego w okresie PRL oraz co ważniejsze, do dziejów kobiet żyjacych w Polsce Ludowej. Uwagi wniesione w recenzji sa drobne i nie rzutuja zasadniczo na wysoką wartość poznawcza pracy.

\section{Bibliografia}

Aktywność publiczna kobiet na ziemiach polskich. Wybrane zagadnienia, red. T. Pudłocki, K. Sierakowska, Warszawa: Wydawnictwo Neriton, 2013, ISBN 978-83-7543-262-6.

Chłosta-Sikorska A., Polityczne uczestnictwo kobiet $w$ zjazdach Polskiej Zjednoczonej Partii Robotniczej z lat 1980-1986. Zarys problematyki [w:] Drogi kobiet do polityki (na przestrzeni XVIII-XXI wieku), red. T. Kulak i M. Dajnowicz, Wrocław: Wydawnictwo Chronicon, 2016, ISBN 978-83-946166-2-5. 
Dajnowicz M., Wzorce aktywności publicznej kobiet $w$ poczatkach transformacji ustrojowej $w$ Polsce $w$ świetle "Kobiety $i$ Życia” $i$ "Urody” (1989-1995) [w:] Drogi kobiet do polityki (na przestrzeni XVIII-XXI wieku), red. T. Kulak i M. Dajnowicz, Wrocław: Wydawnictwo Chronicon, 2016, ISBN 978-83-946166-2-5.

Działaczki społeczne, feministki, obywatelki: Samoorganizowanie się kobiet na ziemiach polskich po 1918 roku (na tle porównawczym), red. A. Janiak-Jasińska, K. Sierakowska, A. Szwarc, Warszawa: Wydawnictwo Neriton, 2008, t. 1, ISBN 978-83-7543-026-4.

Działaczki społeczne, feministki, obywatelki: Samoorganizowanie się kobiet na ziemiach polskich po 1918 roku (na tle porównawczym), t. 2, red. A. Janiak-Jasińska, K. Sierakowska, A. Szwarc, Warszawa: Wydawnictwo Neriton, 2009, ISBN 978-83-7543-101-8.

Fidelis M., Kobiety, komunizm i industrializacja $w$ powojennej Polsce, przeł. Maria Jaszczurowska, Warszawa: Wydawnictwo W. A. B., 2015, ISBN 978-83-280-1532-6.

Kobieta i kultura życia codziennego: wiek XIX i XX: zbiór studiów, red. A. Żarnowska i A. Szwarc, Warszawa: Wydaw. DiG, 1997, t. 5, ISBN 83-85490-94-9.

Kobiety i media. Studia $z$ dziejów emancypacji kobiet, red. P. Perkowski, T. Stegner, Gdańsk: Wydawnictwo Uniwersytetu Gdańskiego, 2009, ISBN 978-83-7326-602-5.

Kobieta $i$ społeczeństwo na ziemiach polskich $w$ XIX wieku: zbiór studiów, red. A. Żarnowska, A. Szwarc, Warszawa: Instytut Historyczny Uniwersytetu Warszawskiego, 1990, ISBN 83-85490-40-X.

Kobieta $i$ świat polityki: Polska na tle porównawczym $w$ XIX $i$ w początkach XX wieku: zbiór studiów, red. A. Żarnowska, A. Szwarc, Warszawa: Instytut Historyczny Uniwersytetu Warszawskiego: DiG, 1994, t. 3, ISBN 83-85490-24-8.

Kobieta $i$ świat polityki $w$ niepodległej Polsce 1918-1939: zbiór studiów, red. A. Żarnowska i A. Szwarc, Warszawa: Wydaw. Sejmowe: Kancelaria Sejmu, 1996, t. 3, cz. 2, ISBN 83-7059-243-0.

Kobieta $w$ gospodarstwie domowym. Ziemie polskie na tle porównawczym, red. K. Sierakowska, G. Wyder, Zielona Góra: Oficyna Wydawnicza Uniwersytetu Zielonogórskiego, 2012, ISBN 978-83-7481-452-2.

Kobiety $w$ wojnach $i$ konfliktach polityczno-społecznych na ziemiach polskich $w$ pierwszej połowie $X X$ wieku, red. T. Kulak i A. Chlebowska, Wrocław: Wydawnictwo Chronicon, 2014, ISBN 978-83-938172-7-6. 
Postawy $i$ aktywność kobiet $w$ czasie powstania styczniowego 18631864 (na tle polskich konspiracji i działalności powstanczej doby zaborowej), red. T. Kulak, J. Dufrat, M. Piotrowska-Marchewa, Wroclaw: Wydawnictwo Chronicon, 2013, ISBN 978-83-935760-4-3.

Stańczak-Wiślicz K., Perkowski P., Dzieje kobiet w PRL - stan i perspektywy badawcze [w:] Dzieje kobiet w Polsce. Dyskusja wokót przyszłej syntezy, pod red. K. A. Makowskiego, Poznań 2014, ISBN 978-8363795-47-4. 